\title{
Pengaruh Rasio Profitabilitas Terhadap Perubahan Harga Saham (Studi Kasus Indeks LQ45) Di Bursa Efek Indonesia
}

\author{
Yayuk Marliza1, Dhimas Redika Dwi Putra² \\ ${ }^{1}$ Manajemen, Universitas Musi Rawas Lubuk Linggau, marlizayayuk77@gmail.com \\ 2Manajemen, Universitas Musi Rawas Lubuk Linggau, dhimasredika.official@gmail.com
}

\begin{abstract}
ABSTRAK
Penelitian ini bertujuan untuk mengetahui pengaruh antara Rasio Profitabilitas yaitu, Gross Profit Margin (GPM), Net Profit Margin (NPM), Return on Investment (ROI), dan Return on Equity (ROE) terhadap perubahan harga saham di Bursa Efek Indonesia Pertukaran (BEI) dengan menggunakan 25 saham perusahaan yang tergabung dalam indeks LQ45 yang telah dilakukan melalui teknik purposive sampling dari beberapa kriteria. Analisis statistik digunakan dalam bentuk uji korelasi parsialitas atau simultan dan regresi linier berganda dengan program E-views 10. Hasil penelitian menunjukkan bahwa rasio korelasi parsial hanya $\mathrm{ROI}$ yang berpengaruh signifikan terhadap perubahan harga saham dengan nilai $t$ hitung sebesar 3.1009. Sedangkan pada uji korelasi simultan, rentabilitas berpengaruh terhadap perubahan harga saham dengan nilai R2 yang disesuaikan 0,0418 . Pengujian pada regresi linier berganda, menggunakan metode Random Effect Model (REM) sebagai metode panel regresi dengan hasil bahwa jika variabel independen NPM, GPM, ROI, dan ROE dinyatakan kurs konstan sehingga rata-rata harga saham adalah sebesar Rp. 8845.183 dengan persamaan regresi $Y=8854.183-164.902 X 1-14.79995 X 2+422.66711 X 3+5,603330 X 4$
\end{abstract}

Kata Kunci : $\quad$ Rasio Profitabilitas, Gross Profit Margin (GPM), Net Profit Margin (NPM), Return on Investment (ROI), Return on Equity (ROE), dan Harga Saham

\begin{abstract}
The aim of this research is to know the effect between Profitability Ratios ie, Gross Profit Margin (GPM), Net Profit Margin (NPM), Return on Investment (ROI), and Return on Equity (ROE) toward stock prices change on Indonesian Stock Exchange (IDX) by using 25 corporate stocks joined in index LQ45 which has been done through a purposive sampling technique of several criteria. The statistical analysis used in the form of correlating test partiality or simultaneous and multiple regression linear with E-views 10 program. The result showed that the partial correlation ratio only ROI which effected was significant on stock prices change with $t$ count value is amounting to 3,1009. While on the simultaneous correlate test profitability ratio is effecting the stock prices change by adjusted $R 2$ value 0.0418. Testing on multiple regression linear, used the Random Effect Model (REM) method as the regression panel method by the result that if independent variables NPM, GPM, ROI, and ROE are stated constant rates so that the stock price average is amounting to Rp. 8845,183 with regression equation $Y=8854,183-164,9072 X 1-14,79995 X 2+422,6711 X 3+5,603330 X 4$.
\end{abstract}

Keyword: Profitability Ratios, Gross Profit Margin (GPM), Net Profit Margin (NPM), Return on Investment (ROI), Return on Equity (ROE), and Stock Prices.

\section{A. PENDAHULUAN}

Pasar modal memiliki peran
penting bagi perekonomian suatu
negara karena pasar modal
menjalankan dua fungsi, yaitu pertama

sebagai sarana bagi pendanaan usaha atau sebagai sarana bagi perusahaan untuk mendapatkan dana dari masyarakat pemodal (investor). Dana yang diperoleh dari pasar modal dapat 
digunakan untuk pengembangan usaha, ekspansi, penambahan modal kerja dan lain-lain. Kedua, pasar modal menjadi sarana bagi masyarakat untuk berinvestasi pada instrumen keuangan, seperti saham, obligasi, reksadana, dan lain-lain. dengan demikian masyarakat dapat menempatkan dana yang dimilikinya sesuai karakteristik keuntungan dan resiko masing-masing instrument.

Pasar modal di Indonesia sendiri dibentuk pada tahun 1912, lebih dahulu dari bursa efek singapura yang dibentuk pada tahun 1930. Saat ini pasar modal Indonesia dikenal dengan sebutan Bursa Efek Indonesia (BEI), yang merupakan gabungan dari Bursa Efek Jakarta dan Bursa Efek Surabaya (Poppy Nurmayanti M, dkk, 2010:15).

Saat ini Bursa Efek Indonesia menjual berbagai Instrumen keuangan jangka panjang, yaitu saham, Surat Utang (Obligasi), Reksadana, Exchange Traded Fund (ETF), dan Derivatif. Salah satu instrumen yang masih banyak diminati oleh para investor Indonesia adalah saham. Saham sendiri dapat diartikan dalam beberapa pengertian yaitu, sebagai tanda bukti penyertaan kepemilikan modal/dana pada suatu perusahaan, kertas yang tercantum dengan jelas nilai nominal, nama perusahaan dan di ikuti dengan hak dan kewajiban yang dijelaskan kepada setiap pemegangnya, dan juga sebagai persediaan yang siap untuk dijual.

Per bulan Mei 2019 telah ada 633 emiten (perusahaan) dari beberapa jenis usaha yang telah listing di Bursa Efek Indonesia (BEI), dari 633 emiten tersebut terdapat 45 emiten yang termasuk dalam perusahaan dengan tingkat likuiditas dan kapitalisasi pasar yang tingi atau sering di sebut dengan Indeks LQ 45.

Indeks LQ 45 ini terdiri dari 45 emiten dengan likuiditas (Liquid) tinggi, yang diseleksi melalui beberapa kriteria pemilihan. Selain penilaian atas likuiditas, seleksi atas emiten-emiten tersebut juga mempertimbangkan kapitalisasi pasar (Bursa Efek Indonesia, 2018). Perusahaanperusahaan yang terdapat dalam indeks LQ 45 inilah yang banyak diminati oleh kalangan investor, hal ini dapat dilihat dari seringnya sahamsaham dari emiten tersebut berfluktuasi atau sering terjadi penjualan dan pembelian saham.

Sebelum menentukan keputusan investasi, investor akan terlebih dahulu melakukan analisis - analisis fundamental secara "top-down" untuk menilai prospek perusahaan. Beberapa analisis fundamental tersebut yaitu, pertama analisis tentang ekonomi yang kemungkinan mempengaruhi keuangan perusahaan di masa yang akan datang, kedua analisis tentang prospek perusahaan secara horizontal yaitu membandingkan perusahaanperusahaan dari sektor usaha yang sama, yang terakhir adalah melakukan analisis terhadap bagaimana kondisi dari internal perusahaan tersebut termasuk menganalisis kondisi keuangan perusahaan seperti melihat profit perusahaan jika ditinjau dari rasio profitabilitas.

Dalam studi empiris yang dilakukan oleh Mochamat Feri (2014) dengan menggunakan perusahaanperusahaan properti di Bursa Efek Indonesia (BEl) yang listing pada periode 2008-2012 mengemukakan bahwa dari beberapa rasio profitabilitas, yaitu Operating Profit Margin (OPM), Net Profit Margin (NPM), Returnon Equity (ROE), dan Returnon Aset (ROA). Hanya ROE yang secara signifikan mempengaruhi keputusan investasi para investor dalam membeli saham suatu emiten. 


\section{B. KAJIAN TEORI}

1) Rasio Profitabilitas.

Rasio ini mengukur efektivitas manajemen secara keseluruhan yang ditujukan oleh besar kecilnya tingkat keuntungan yang diperoleh dalam hubungannya dengan penjualan maupun investasi. Semakin baik rasio profitabilitas maka semakin baik menggambarkan kemampuan tingginya perolehan keuntungan perusahaan (Irham Fahmi, 2013:135).

Rasio profitabilitas digunakan untuk mengukur tingkat imbalan atau perolehan (keuntungan) di banding dengan penjualan atau aktiva, mengukur seberapa besar kemampuan perusahaan memperoleh laba dalam hubungan dengan penjualan, aktiva maupun laba dan modal sendiri. (V. Wiratna Sujarweni, 2017:64)

Berdasarkan beberapa definisi diatas maka dapat disimpulkan bahwa rasio profitabilitas merupakan alat ukur yang digunakan untuk mengetahui kinerja suatu perusahaan yang diukur melalui keuntungan yang didapatkan melalui penjualan dan investasi yang dilakukannya.

\section{Jenis- jenis Rasio Profitabilitas}

Rasio profitabilitas secara umum ada 4 (Irham fahmi, 2013:135), yaitu :

\section{a. Gross Profit Margin}

Rasio gross profit margin merupakan margin laba kotor. Joel G. Siegel dan Jae K. Shim dalam buku irham fahmi mengatakan bahwa "Persentase dari sisa penjualan sebuah perusahaan membayar barangnya juga disebut margin keuntungan kotor (gross profit margin). Adapun rumus dari rasio gross profit margin adalah :

$$
\frac{\text { Sales - Cost of Good Sold }}{\text { Sales }}
$$

b. Net Profit Margin

Rasio net profit margin disebut juga dengan rasio pendapatan terhadap penjualan. Margin laba yang tinggi lebih disukai karena menunjukkan bahwa perusahaan mendapat hasil yang baik yang melebihi harga pokok penjualan.

Adapun rumus rasio net profit margin adalah :

Earning After Tax (EAT)
Sales

Laba setelah pajak ini dianggap sebagai laba bersih. Karena itu di beberapa literature ditemukan jika earning after tax ditulis dengan net profit atau laba bersih.

\section{c. Return on Invesment (ROI)}

Rasio return on investment (ROI) atau pengembalian investasi, bahwa di beberapa referensi ditulis dengan return on assets (ROA). Hasil pengembalian investasi atau lebih dikenal dengan nama Returnoninvestment (ROI) atau retur non total assets merupakan rasio yang menunjukkan hasil (return) atas jumlah aktiva yang digunakan dalam perusahaan (Kasmir, 204:2019). Rasio ini melihat sejauh mana investasi yang telah ditanamkan mempu memberikan pengembalian keuntungan sesuai dengan yang diharapkan. Adapun rumus dari $\mathrm{ROI}$ adalah :

\section{Earning After Tax (EAT) \\ Total Assets}

\section{d. Return on Equity (ROE)}

Rasio return on equity ( $\mathrm{ROE}$ ) disebut juga dengan laba atas equity. Di beberapa referensi juga disebut dengan rasio total assets turnover. Atau perputaran total asset. Rasio ini mengkaji sejauh mana suatu perusahaan mempergunakan sumber 
daya yang dimiliki untuk mampu memberikan laba atas sekuitas.Adapun rumus Return on Equity (ROE) adalah :

\section{Earning After Tax (EAT) \\ Shareholders Equity}

\section{2) Saham.}

Saham dapat didefinisikan sebagai tanda penyertaan modal seseorang atau pihak (badan usaha) dalam suatu perusahaan atau perseroan terbatas. Dengan menyertakan modal tersebut, maka pihak tersebut memiliki klaim atas pendapatan perusahaan, klaim atas asset perusahaan, dan berhak hadir dalam Rapat Umum Pemegang Saham (RUPS). (Bursa Efek Indonesia).

Harga saham adalah harga suatu saham yang terjadi di pasar bursa pada saat tertentu yang ditentukan oleh pelaku pasar dan ditentukan oleh permintaan dan penawaran saham yang bersangkutan di pasar modal (Jogiyanto, 2008:167).

Harga saham menentukan
kekayaan Memaksimalisasi kekayaan pemegang saham diterjemahkan menjadi memaksimalkan harga saham perusahaan. Harga saham pada waktu tertentu akan bergantung pada arus kas yang diharapkan diterima di masa depan oleh investor "rata-rata" jika investor membeli saham (Brigham dan houston (2010:27).

Hipotesis dalam penelitian ini dirumuskan sebagai berikut:

\section{a) Pengaruh Gross Profit Margin terhadap perubahan harga saham}

Gross Profit Margin (GPM) merupakan rasio yang digunakan untuk mengukur laba kotor dari suatu perusahaan dengan menggunakan volume penjualan dan harga pokok penjualan sebagai pembandingnya. Mengenai gross profit margin Lyn M. Fraser dan Aileen Ormiston memberikan pendapatnya yaitu “ Margin laba kotor, yang memperlihatkan hubungan antara penjualan dan harga pokok penjualan, mengukur kemampuan sebuah perusahaan untuk mengendalikan biaya persediaan atau biaya operasi barang maupun untuk meneruskan kenaikan harga lewat penjualan kepada pelanggan " (Irham Fahmi, 2013:136). Dengan adanya peningkatan kinerja perusahaan dari segi margin laba kotor diharapkan akan juga meningkatkan investasi pada perusahaan.

$$
\begin{aligned}
\mathrm{H}_{0}= & \begin{array}{l}
\text { Gross Profit Margin } \\
\text { secara }
\end{array} \\
& \begin{array}{r}
\text { (GPM) } \\
\text { berpengaruh secara signifikan } \\
\text { terhadap perubahan harga }
\end{array} \\
& \text { saham } \\
\mathrm{H}_{\mathrm{a}}= & \text { Gross Profit Margin (GPM) } \\
& \text { secara parsial berpengaruh } \\
& \text { secara seginfikan terhadap } \\
& \text { perubahan harga saham }
\end{aligned}
$$

\section{b) Pengaruh Net Profit Margin terhadap perubahan harga saham}

Dengan memeriksa margin laba dan norma industri sebuah perusahaan pada tahun-tahun sebelumnya, investor dapat menilai efesiensi operasi dan strategi penetapan harga serta status persaingan perusahaan dengan perusahaan lain dalam industri tersebut. Margin laba yang tinggi lebih disukai karena menunjukkan bahwa perusahaan mendapat hasil yang baik melebihi harga pokok penjualan sehingga secara signifikan dapat 
mempengaruhi pengambilan keputusan oleh investor.

$$
\begin{aligned}
\mathrm{H}_{0}= & \text { Net Profit Margin } \\
& \text { secara parisal tidak } \\
& \begin{array}{r}
\text { berpengaruh secara signifikan } \\
\text { terhadap perubahan harga }
\end{array} \\
& \text { saham } \\
\mathrm{H}_{\mathrm{a}=} & \text { Net Profit Margin (NPM) } \\
& \text { secara parsial berpengaruh } \\
& \text { secara signifikan terhadap } \\
& \text { perubahan harga saham }
\end{aligned}
$$

\section{C) Pengaruh Return on Invesment (ROI) terhadap perubahan harga saham}

Rasio ini melihat sejauh mana investasi yang telah di tanamkan mampu memberikan pengembalian keuntungan sesuai dengan yang diharapkan (Irham Fahmi, 2013:137).

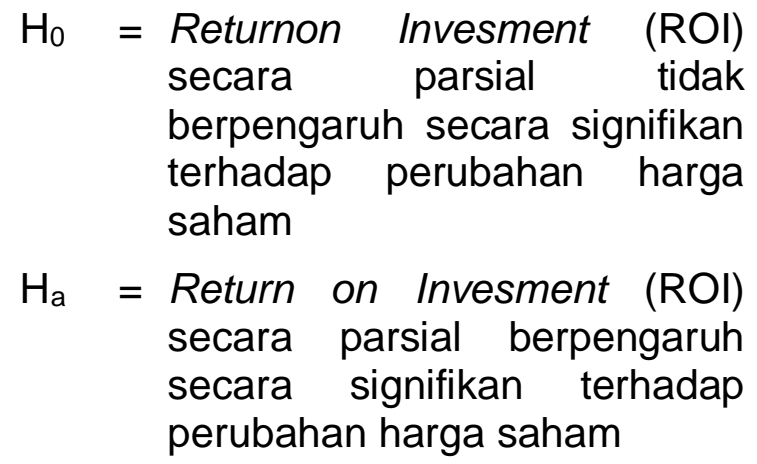

\section{d) Pengaruh Returnon Equity (ROE) terhadap perubahan harga saham}

Rasio ini menggambarkan sejauh mana perusahaan dapat mendapatkan laba melalui sumber daya yang dipergunakan untuk keperluan operasional. Sehingga dengan adanya informasi peningkatan dari rasio ini maka akan mempengaruhi keputusan berinvestasi dari para investor yang tentunya juga akan meningkatkan harga saham dari suatu perusahaan dikarenakan imbal hasil atau returnyang di tawarkan juga meningkat.

$$
\begin{aligned}
\mathrm{H}_{0}= & \text { Returnon Equity (ROE) secara } \\
& \text { parsial tidak berpengaruh } \\
& \text { secara signifikan terhadap } \\
& \text { perubahan harga saham } \\
\mathrm{H}_{\mathrm{a}}= & \text { Returnon Equity (ROE) secara } \\
& \text { parsial berpengaruh secara } \\
& \text { signifikan terhadap perubahan } \\
& \text { harga saham }
\end{aligned}
$$

e) Besarnya pengaruh GPM, NPM, ROI, dan ROE terhadap perubahan harga saham

$$
\begin{aligned}
\mathrm{H}_{0}= & \text { Koefesien regresi antara GPM, } \\
& \text { NPM, ROI, dan ROE terhadap } \\
& \text { perubahan harga saham tidak } \\
& \text { dapat dijelaskan secara } \\
& \text { signifikan } \\
\mathrm{H}_{\mathrm{a}}= & \text { Koefesien regresi antara GPM, } \\
& \text { NPM, ROI, dan ROE terhadap } \\
& \text { perubahan harga saham dapat } \\
& \text { dijelaskan secara signifikan. }
\end{aligned}
$$

\section{METODE PENELITIAN}

Jenis penelitian yang penulis gunakan dalam penelitian ini adalah jenis penelitian kuantitatif dengan metode asosiatif. Metode penelitian asosiatif merupakan penelitian yang bertujuan untuk mengetahui pengaruh ataupun juga hubungan antara dua variabel atau lebih (Sugiyono, 2013:11).

Lokasi Penelitian ini dilakukan pada Bursa Efek Indonesia (BEI) dengan menggunakan laporan ringkasan performa perusahaan LQ 45 tahun 2012-2017, perusahaan LQ 45 yang digunakan merupakan perusahaan yang terdaftar sebagai perusahaan dengan likuiditas dan kapitalisasi pasar tertinggi pada agustus 2018.

Sampel Pada penelitian ini adalah perusahaan-perusahaan yang telah listing di Bursa Efek Indonesia (BEI) yang terdaftar sebagai 45 
perusahaan-perusahaan

dengan tingkat likuiditas dan kapitalisasi pasar terbesar (Indeks LQ 45) sebagai sampelnya. Untuk sampel pada penelitian ini penulis menggunakan 25 perusahaan yang terdaftar sebagai perusahaan Indeks LQ 45 tahun 20122018. Dengan pendekatan data panel atau kombinasi antara cross-section dan timeseries maka semua terdapat 150 data observasi.

Pada penelitian ini penulis menggunakan teknik pengambilan sampel berupa Purposive Sampling secara convenience sampling secara dengan menggunakan 3 kriteria yang dirasakan sesuai dengan tujuan penelitian yang diharapkan oleh penulis, antara lain :

\section{a. 25 perusahaan dengan kapitalisasi pasar terbesar menurut ringkasan performa perusahaan LQ 45 bulan agustus 2018}

b. Merupakan perusahaan berstatus tetap sebagai perusahaan indeks LQ 45 selama 6 tahun terakhir

c. Menyajikan secara lengkap data ringkasan performa perusahaan selama 6 tahun

d. Perusahaan non-keuangan dan jasa sehingga data yang diteliti oleh penulis meruapakan data yang tidak bias.

Data yang digunakan dalam penelitian ini adalah data sekunder, yaitu dengan menggunakan laporan ringkasan performa perusahaan LQ 45 yang telah dipublikasikan oleh Bursa Efek Indonesia (BEI) di laman website www.idx.co.id. metode pengumpulan data dilakukan dengan dokumentasi, hal ini dikarenakan penulis menggunakan data yang berasal dari laporan ringkasan performa perusahaan Indeks LQ 45.
Analisa data yang penulis gunakan dalam penelitian ini tergolong dalam data kuantitatif dikarenakan penulis menggunakan angka - angka rasio yang terdapat didalamlaporan ringkasan performa Indeks LQ45. Dalam melakukan penelitian dan pengolahan data variable independen dan variable dependen penulis menggunakan program statistic Econometrika Views (E-views 10). Eviews merupakan salah satu software analisis data multivariat dan ekonometrika yang cukup terkenal karena kemampuannya mengolah berbagai jenis data seperti crosssectional, timeseries, dan panel (Imam Ghozali, dkk, 13:2017).

Pada penelitian ini penulis menggunakan statistik inferensial parametris, hal ini dikarenakan pada penelitian ini penulis akan menguji parameter populasi melalui data sampling serta akan diuji melalui uji goodness of fit yaitu uji $\mathrm{F}$ table dan uji $\mathrm{t}$ table.

\section{HASIL DAN PEMBAHASAN}

Dalam penelitian ini penulis menggunakan rasio profitabilitas yaitu Net Profit Margin (NPM), Gross Profit Margin (GPM), Return On Investment / Assets (ROI), dan Return On Equity (ROE) sebagai variabel independent atau variabel bebas dan harga saham dari 25 perusahaan LQ 45 sebagai variabel dependent atau variabel terikat. Seluruh data yang digunakan dalam penelitian ini diambil melalui website resmi Bursa Efek Indonesia (BEI) yaitu www.idx.co.id. Bursa Efek Indonesia merupakan satu - satunya Pasar Modal yang dimiliki oleh Indonesia yang mempunyai kegiatan memperjual - belikan instrumeninstrumen keuangan seperti : Saham, Obligasi, Reksadana, Derivatif dan instrumen keuangan yang lainnya. 


\section{Uji Asumsi Klasik}

Uji asumsi klasik merupakan pengujian yang wajib dilakukan apabila penulis ingin melakukan pengujian secara korelasi dan regresi, hasil dari pengujian ini akan terlihat seberapa layakkah data tersebut untuk di uji, ada beberapa kriteria pengujian yang harus terpenuhi terlebih dahulu sebelum melakukan pengujian korelasi maupun regresi, antara lain :

\section{a. Uji Normalitas}

Penulis menggunakan uji normalitas dengan metode Jarque Bera melalui eviews 10, dengan hasil output sebagai berikut :

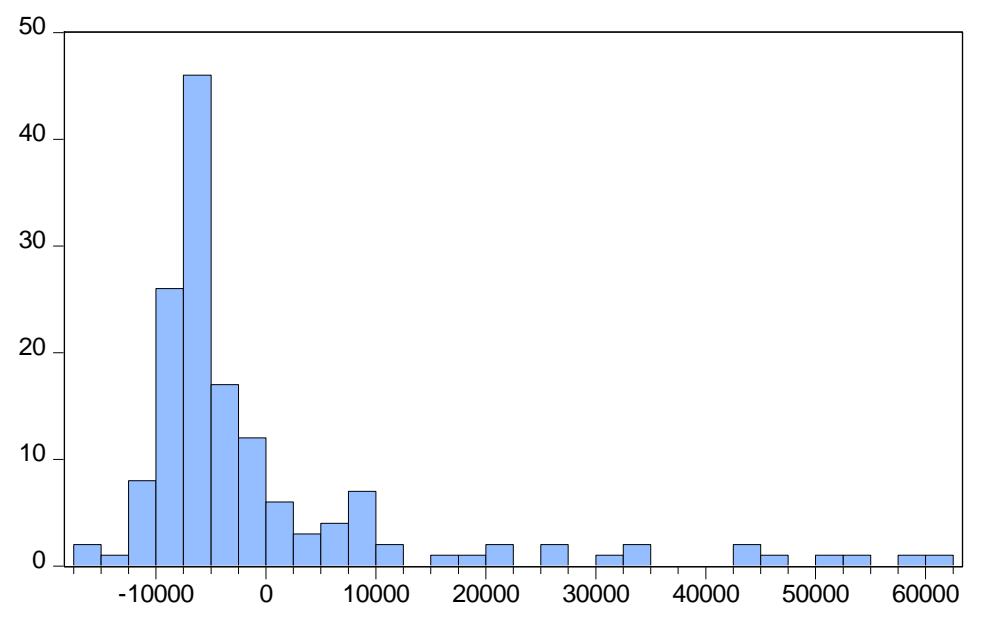

$\begin{array}{ll}\text { Series: Standardized Residuals } \\ \text { Sample 2012 } 2017 \\ \text { Observations } & 150 \\ & \\ \text { Mean } & -7.28 \mathrm{e}-14 \\ \text { Median } & -5825.476 \\ \text { Maximum } & 60654.90 \\ \text { Minimum } & -15082.77 \\ \text { Std. Dev. } & 14518.09 \\ \text { Skewness } & 2.440670 \\ \text { Kurtosis } & 8.823127 \\ & \\ \text { Jarque-Bera } & 360.8518 \\ \text { Probability } & 0.000000\end{array}$

\section{Gambar Uji Jarque-Bera}

Berdasarkan dasar pengambilan keputusan, bahwa :

Apabila output memperlihatkan bahwa nilai signifikansi diatas 0,05 maka nilai residual tersebut normal, sebaliknya apabila nilai signifikansi tabel di bawah 0,05 maka nilai residual tersebut tidak normal.

Dari hasil output pengujian normalitas menggunakan program Eviews 10 dapat dilihat bahwa nilai Jarque-Bera sebesar 360,8518 dan signifikan dengan nilai $\mathrm{p}$ sebesar 0,000 . Oleh karena itu, dapat disimpulkan bahwa $\mathrm{H}_{0}$ yang menyatakan bahwa residual berdistribusi normal dapat ditolak. Dengan kata lain, asumsi residual terdistribusi normal tidak terpenuhi.

Menurut Dosen Perbanas dalam websitenya dosen. perbanas. id mengemukakan bahwa Uji normalitas pada dasarnya tidak merupakan syarat BLUE (Best Linear Unbias Estimator) dan beberapa pendapat tidak mengharuskan syarat ini sebagai sesuatu yang wajib dipenuhi.

\section{b. Uji Multikolinearitas}

Pada bagian ini penulis ingin menguji apakah antarvariabel independen ditemukan korelasi yang sempurna pada model regresi, dengan hasil output sebagai berikut : 
Tabel Uji Multikolinearitas

\begin{tabular}{|c|l|l|l|l|}
\hline & NPM & GPM & ROI & ROE \\
\hline NPM & 1.000000 & 0.819663 & 0.383219 & 0.124340 \\
\hline GPM & 0.819663 & 1.000000 & 0.545083 & 0.249072 \\
\hline ROI & 0.383219 & 0.545083 & 1.000000 & 0.485668 \\
\hline ROE & 0.124340 & 0.249072 & 0.485668 & 1.000000 \\
\hline
\end{tabular}

Berdasarkan pada hasil output matrik korelasi di atas korelasi antara variabel NPM dan GPM sebesar 0,819663, korelasi antara variabel NPM dan ROI sebesar 0,383219, korelasi antara variabel NPM dan ROE sebesar 0,124340, korelasi antara variabel GPM dan ROI sebesar 0,545083 , korelasi antara variabel $\mathrm{ROI}$ dan ROE sebesar 0,485668. Sehingga dapat disimpulkan bahwa tidak terdapat multikolinearitas antarvariabel independen, hal ini dikarenakan tidak ada nilai diatas 0,90 antarvariabel independen.

Menurut Dosen Perbanas dalam websitenya dosen perbanas. id mengemukakn bahwa Multikolinearitas perlu dilakukan pada saat regresi linear menggunakan lebih dari satu variabel bebas. Jika variabel bebas hanya satu, maka tidak mungkin terjadi multikolinearitas. Sehingga pada penelitian ini diwajibkan menggunakan uji multikolinearitas.

\section{c. Uji Heterokedastisitas}

Uji heterokedastisitas yang dilakukan oleh penulis digunakan untuk mengetahui apakah pada data pada model regresi nantinya terjadi ketidaksamaan variansi dari residual dari satu pengamatan ke pengamatan yang lain. Pengujian dilakukan menggunakan program Eviews 10 dengan menggunakan metode Glejser.

\section{Tabel Uji Heterokedastisitas}

Dependent Variable: RESABS

Method: Panel EGLS (Cross-section random effects)

Date: 07/10/19 Time: 22:17

Sample: 20122017

Periods included: 6

Cross-sections included: 25

Total panel (balanced) observations: 150

Swamy and Arora estimator of component variances

\begin{tabular}{lllll}
\hline \hline Variable & Coefficient & Std. Error & t-Statistic & Prob. \\
\hline \hline C & 8868.184 & 2698.311 & 3.286569 & 0.0013 \\
NPM & -84.82559 & 100.4806 & -0.844199 & 0.3999 \\
GPM & -162.0557 & 89.24559 & -1.815840 & 0.0715 \\
ROI & 565.9426 & 96.89481 & 5.840793 & 0.0000 \\
ROE & -16.57431 & 6.592422 & -2.514146 & 0.0130 \\
\hline \hline
\end{tabular}


Dari hasil output uji heterokedastisitas menggunakan uji glejser melalui Eviews 10 dapat dilihat bahwa variabel Net Profit Margin (NPM) dan Gross Profit Margin (GPM) memiliki nilai $p$ yaitu 0,3999 dan 0,0715 yang berarti tidak signifikan sehingga terjadi heterokedastisitas. Sedangkan variabel Return on Investment (ROI) dan Return on Equity
(ROE) memiliki nilai $p$ kurang dari 0,05 yaitu 0,000 dan 0,0130 sehingga dapat disimpulkan bahwa variabel ROI dan ROE tidak terjadi heterokedastisitas.

\section{d. Uji Autokorelasi}

Pada pengujian ini penulis menggunakan uji autokorelasi dengan metode Durbin-watson, dengan hasil output sebagai berikut :

\section{Tabel Uji Durbin-Watson}

Weighted Statistics

\begin{tabular}{llll}
\hline \hline R-squared & 0.067557 & Mean dependent var & 3123.686 \\
Adjusted R-squared & 0.041835 & S.D. dependent var & 7658.099 \\
S.E. of regression & 7496.201 & Sum squared resid & $8.15 E+09$ \\
F-statistic & 2.626380 & Durbin-Watson stat & 0.907506 \\
Prob(F-statistic) & 0.037009 & & \\
\hline \hline
\end{tabular}

Berdasarkan dasar pengambilan keputusan, bahwa :

- $\quad \mathrm{DU}<\mathrm{DW}<4$-DU maka diterima yang berarti tak terjadi autokorelasi

- $\quad \mathrm{DW}<\mathrm{DL}$ atau $\mathrm{DW}>4-\mathrm{DL}$ maka ditolak yang berarti terjadi autokorelasi

- $\quad \mathrm{DL}<\mathrm{DW}<\mathrm{DU}$ atau 4-DU $<\mathrm{DW}$ $<$ 4-DL berarti taka da kesimpulan yang pasti

Dari hasil output uji durbinwatson didapatkan nilai dW sebesar 0,907506 , sehingga dapat disimpulkan bahwa nilai $\mathrm{dW}<\mathrm{dL}$ yaitu 1,6926 yang berarti pada model regresi terjadi autokorelasi positif.

Menurut Dosen Perbanas dalam websitenya dosen. Perbanas id mengemukakan bahwa Autokorelasi hanya terjadi pada data time series. Pengujian autokorelasi pada data yang tidak bersifat time series (cross section atau panel) akan sia - sia semata atau tidaklah berarti.

\section{Korelasi Parsial}

Pengujian korelasi secara parsial dilakukan dengan membandingkan antar variabel dengan variabel terikat. Berikut merupakan hasil ouput dari pengolahan data korelasi parsial :

Tabel Korelasi Parsial

\begin{tabular}{|l|l|l|l|l|l|}
\hline & SAHAM & NPM & GPM & ROI & ROE \\
\hline SAHAM & 1.000000 & -0.005720 & -0.001961 & 0.485777 & 0.191096 \\
\hline NPM & -0.005720 & 1.000000 & 0.819663 & 0.383219 & 0.124340 \\
\hline
\end{tabular}




\begin{tabular}{|l|l|l|l|l|l|}
\hline GPM & -0.001961 & 0.819663 & 1.000000 & 0.545083 & 0.249072 \\
\hline ROI & 0.485777 & 0.383219 & 0.545083 & 1.000000 & 0.485668 \\
\hline ROE & 0.191096 & 0.124340 & 0.249072 & 0.485668 & 1.000000 \\
\hline
\end{tabular}

Berdasarkan pedoman interprestasi korelasi parsial, bahwa : $0,00-0,199=$ Sangat lemah $0,20-0,399=$ Lemah $0,40-0,599=$ Sedang $0,60-0,799=$ Kuat $0,80-1,000=$ Sangat Kuat Berikut interprestasi dari tabel di atas :

Berdasarkan hasil output korelasi parsial menggunakan program Eviews 10 maka didapatkan bahwa variabel NPM tergolong pada korelasi yang sangat lemah terhadap harga saham hal ini dikarenakan nilai variabel NPM menunjukkan nilai $-0,005720$, variabel GPM juga tergolong kedalam korelasi yang sangat lemah terhadap harga saham hal ini ditunjukkan dengan nilai korelasi -0,001961, variabel ROI tergolong kedalam korelasi sedang terhadapm harga saham hal ini ditunjukkan dengan nilai korelasi 0,485777 , sedangkan variabel $\mathrm{ROE}$ sendiri tergolong kedalam korelasi yang sangat lemah terhadap harga saham hal ini ditunjukkan dengan nilai korelasi 0,191096.

\section{Pemilihan Model Persamaan Regresi}

\section{a. Ordinary Least Squares (OLS) atau Common Model}

Berikut ini merupakan hasil output regresi menggunakan model OLS :

\section{Tabel Regression Ordinary Least Squares (Ols) Model}

Dependent Variable: SAHAM

Method: Panel Least Squares

Date: 07/09/19 Time: 01:49

Sample: 20122017

Periods included: 6

Cross-sections included: 25

Total panel (balanced) observations: 150

\begin{tabular}{lllll}
\hline \hline Variable & Coefficient & Std. Error & t-Statistic & Prob. \\
\hline \hline C & 10836.74 & 2265.795 & 4.782755 & 0.0000 \\
NPM & 170.9756 & 176.9114 & 0.966448 & 0.3354 \\
GPM & -433.1571 & 117.7614 & -3.678259 & 0.0003 \\
ROI & 1024.781 & 124.6900 & 8.218626 & 0.0000 \\
ROE & -13.62532 & 17.77927 & -0.766360 & 0.4447 \\
\hline \hline R-squared & 0.344808 & Mean dependent var & 11390.10 \\
Adjusted R-squared & 0.326734 & S.D. dependent var & 16454.95 \\
S.E. of regression & 13501.75 & Akaike info criterion & 21.89179 \\
Sum squared resid & $2.64 \mathrm{E}+10$ & Schwarz criterion & 21.99215 \\
Log likelihood & -1636.884 & Hannan-Quinn criter. & 21.93256 \\
F-statistic & 19.07733 & Durbin-Watson stat & 0.431919 \\
Prob(F-statistic) & 0.000000 & & &
\end{tabular}


Berdasarkan output pada model regresi OLS didapatkan hasil bahwa nilai probabilitas (<) kurang dari 0,05 menunjukkan bahwa variabel GPM dan ROI secara parsial berpengaruh signifikan terhadap harga saham. Variabel GPM menunjukkan nilai negatif yang berarti mempunyai slope negatif terhadap perubahan harga saham dengan nilai koefesien GPM yaitu $-433,1571$. Variabel ROI menunjukkan pengaruh positif terhadap perubahan harga saham dengan nilai koefesien ROI sebesar 1024,781. Sedangkan variabel NPM dan ROE menunjukkan bahwa secara signifikan tidak memiliki pengaruh terhdap perubahan harga saham hal ini dikarenakan nilai probability (>) lebih dari 0,05. Namun dapat dilihat bahwa nilai Standard Error of Estimate Regression yang besar, yaitu 13501,75 yang mengindikasikan bahwa model regresi kurang tepat dalam memprediksi variabel indpenden. Sehingga penulis harus melakukan analisis model regresi yang kedua yaitu Fixed Effect Model.

\section{b. The Fixed Effect Model (FEM) atau Least Squares Dummy Variabel (LSDV) Regression Model}

Berikut ini merupakan hasil output dari analisis Fixed Effect Model (FEM) :

Dependent Variable: SAHAM

Tabel Model Regresi Fixed Effect (Fem)

Method: Panel Least Squares

Date: 07/09/19 Time: 01:51

Sample: 20122017

Periods included: 6

Cross-sections included: 25

Total panel (balanced) observations: 150

\begin{tabular}{lllll}
\hline \hline Variable & Coefficient & Std. Error & t-Statistic & Prob. \\
\hline \hline C & 5916.149 & 4824.607 & 1.226245 & 0.2225 \\
NPM & -83.29273 & 169.6990 & -0.490826 & 0.6244 \\
GPM & 162.4065 & 182.3742 & 0.890513 & 0.3750 \\
ROI & 98.36288 & 174.4043 & 0.563993 & 0.5738 \\
ROE & 8.260784 & 9.608172 & 0.859766 & 0.3916 \\
\hline \hline
\end{tabular}

Effects Specification

Cross-section fixed (dummy variables)

\begin{tabular}{llll}
\hline \hline R-squared & 0.850142 & Mean dependent var & 11390.10 \\
Adjusted R-squared & 0.815464 & S.D. dependent var & 16454.95 \\
S.E. of regression & 7068.671 & Akaike info criterion & 20.73655 \\
Sum squared resid & $6.05 \mathrm{E}+09$ & Schwarz criterion & 21.31861 \\
Log likelihood & -1526.242 & Hannan-Quinn criter. & 20.97303 \\
F-statistic & 24.51531 & Durbin-Watson stat & 1.174197 \\
Prob(F-statistic) & 0.000000 & & \\
\hline \hline
\end{tabular}


Berdasarkan hasil output menggunakan fixed effect model (FEM) terlihat bahwa semua variabel independen secara parisal tidak berpengaruh terhadap harga saham, hal ini dapat terlihat dari nilai probability yang diatas nilai signifikan yaitu 0,05 , bahkan variabel $R O I$ dan GPM yang sebelumnya berpengaruh secara signifikan, pada pengujian fixed effect model (FEM) tidak berpengaruh bahkan nilai probability nya lebih besar dari variabel NPM dan ROE. Namun jika dilihat dari besarnya nilai Standard Error Estimate of Regression yang cenderung lebih kecil daripada model sebelumnya, hal ini menandakan bahwa model regresi fixed effect lebih tepat dari memprediksi variabel dependen.

\section{Uji Perbandingan Chow (Ordinary Least Squares (OLS) Model vs Fixed Effect Model (FEM))}

Uji perbandingan dilakukan untuk menguji manakah model pengujian regresi yang lebih baik, antara Ordinary Least Squares (OLS) dan Fixed Effect Model (FEM), dengan hipotesis sebagai berikut :

$\mathrm{H}_{0}$ : Model fixed effect sama dengan model pooled OLS

$\mathrm{H}_{\mathrm{a}}$ : Model fixed effect lebih baik dibandingkan model pooled OLS

Jika nilai $F$ signifikan maka berarti model fixed effect lebih baik dibandingkan model pooled OLS atau dengan kata lain model fixed effect memberikan nilai tambah signifikan dibandingkan dengan pooled OLS. Berikut ini adalah hasil output dari Uji Chow.

\section{Tabel Uji Chow}

Redundant Fixed Effects Tests

Equation: Untitled

Test cross-section fixed effects

\begin{tabular}{llll}
\hline \hline Effects Test & Statistic & d.f. & Prob. \\
\hline \hline Cross-section F & 17.000849 & $(24,121)$ & 0.0000 \\
Cross-section Chi-square & 221.285460 & 24 & 0.0000 \\
\hline \hline
\end{tabular}

Berdasarkan hasil output uji chow dapat dilihar bahwa nilai cross section F signifikan $(<0,05)$ yang berarti $\mathrm{H}_{0}$ tidak dapat diterimadengan kata lain bahwa model fixed effect lebih baik daripada model pooled OLS model. Walaupun fixed effect lebih baik daripada model pooled OLS namun model fixed effect memiliki beberapa permasalahan yang dapat muncul, seperti (Imam Ghozali dan Dwi Ratmono, 244:2017) :

1. Jika kita memasukkan banyak dummy (contoh model intersep antar waktu antar individu), akan mengurangi degree of freedom (df).

2. Jika terlalu banyak variabel di dalam model, akan mengarah kepada terjadinya multikolinearitas yang dapat menyebabkan ketepatan estimasi parameter menjadi menurun.

3. Jika menggunakan variabel dummy seperti jenis kelamin, suku, dan lain -lain, akan menyulitkan mengidentifikasi 
besaran koefesien dummy perbedaan intersep karena variabel - variabel tersebut tidak berubah sepanjang waktu (time variant). Model LSDV mungkin tidak mampu mengidentifikasi pengaruh dari variabel -variabel time variant.

4. Untuk error term, karena merupakan error cross section dan time series, asumsi klasik yang dimasukkan dapat mengalami modifikasi.
Menurut Gujarati (2003, hak 647) dalam buku Imam Ghozali dan Dwi Ratmono (244:2017) mencatat bahwa beberapa masalah di atas dapat diatasi dengan menggunakan model random effect (REM).

\section{c. Random Effect Model (REM) atau Error Components Model (ECM)}

Berikut ini merupakan hasil output model regresi menggunakan Random Effect Model (REM) :

\section{Tabel Random Effect Model (Rem)}

Dependent Variable: SAHAM

Method: Panel EGLS (Cross-section random effects)

Date: 07/09/19 Time: 01:55

Sample: 20122017

Periods included: 6

Cross-sections included: 25

Total panel (balanced) observations: 150

Swamy and Arora estimator of component variances

\begin{tabular}{|c|c|c|c|c|}
\hline Variable & Coefficient & Std. Error & t-Statistic & Prob. \\
\hline $\begin{array}{l}\text { C } \\
\text { NPM } \\
\text { GPM } \\
\text { ROI } \\
\text { ROE }\end{array}$ & $\begin{array}{l}8854.183 \\
-164.9072 \\
-14.79995 \\
422.6711 \\
5.603330\end{array}$ & $\begin{array}{l}3667.182 \\
143.1716 \\
124.4321 \\
136.3019 \\
9.576447\end{array}$ & $\begin{array}{l}2.414438 \\
-1.151816 \\
-0.118940 \\
3.100991 \\
0.585116\end{array}$ & $\begin{array}{l}0.0170 \\
0.2513 \\
0.9055 \\
0.0023 \\
0.5594\end{array}$ \\
\hline & \multicolumn{2}{|c|}{ Effects Specification } & S.D. & Rho \\
\hline \multirow[t]{2}{*}{$\begin{array}{l}\text { Cross-section random } \\
\text { Idiosyncratic random }\end{array}$} & & & $\begin{array}{l}10119.14 \\
7068.671\end{array}$ & $\begin{array}{l}0.6721 \\
0.3279\end{array}$ \\
\hline & \multicolumn{4}{|c|}{ Weighted Statistics } \\
\hline \multirow[t]{2}{*}{$\begin{array}{l}\text { R-squared } \\
\text { Adjusted R-squared } \\
\text { S.E. of regression } \\
\text { F-statistic } \\
\text { Prob(F-statistic) }\end{array}$} & $\begin{array}{l}0.067557 \\
0.041835 \\
7496.201 \\
2.626380 \\
0.037009\end{array}$ & \multicolumn{2}{|c|}{$\begin{array}{l}\text { Mean dependent var } \\
\text { S.D. dependent var } \\
\text { Sum squared resid } \\
\text { Durbin-Watson stat }\end{array}$} & $\begin{array}{l}3123.686 \\
7658.099 \\
8.15 \mathrm{E}+09 \\
0.907506\end{array}$ \\
\hline & \multicolumn{3}{|c|}{ Unweighted Statistics } & \\
\hline $\begin{array}{l}\text { R-squared } \\
\text { Sum squared resid }\end{array}$ & $\begin{array}{l}0.221559 \\
3.14 \mathrm{E}+10\end{array}$ & $\begin{array}{l}\text { Mean de } \\
\text { Durbin- }\end{array}$ & $\begin{array}{l}\text { endent var } \\
\text { atson stat }\end{array}$ & $\begin{array}{l}11390.10 \\
0.235448\end{array}$ \\
\hline
\end{tabular}


Berdasarkan hasil uji regresi menggunakan model Random Effect didapatkan hasil bahwa variabel ROI berpengaruh secara parsial dan signifikan dengan nilai probability $(0,0023<0,05)$ serta berpengaruh positif terhadap variabel dependen, yaitu 422.6711. Sedangkan variabel NPM, GPM, dan ROE tidak berpengaruh secara signifikan terhadap variabel dependen yaitu harga saham, hal ini dikarenakan nilai probability untuk variable NPM , GPM, dan ROE di atas nilai signifikansi 0,05. Hal ini justru berkaitan dengan hasil korelasi parsial yang menunjukkan bahwa variabel ROI berpengaruh terhadap harga saham yang tergolong dalam golongan "Sedang". Sedangkan jika dilihat dari nilai Standard Error of Regression juga tidak beda jauh dari pengujian regresi dengan model fixed effect. Selain itu ada beberapa perimbangan yang dapat dijadikan sebagai acuan dalam perbandingan antara model fixed effect dan random effect, yang telah dibahas pada BAB III sebelumnya bahwa :

"Apabila N (sampel/observasi) besar dan $T$ (runtun waktu) kecil dan asumsi - asumsi REM terpenuhi yaitu apabila jumlah cross section lebih besar daripada jumlah variabel penelitian. Maka hasil estimasi REM lebih efisien dibandingkan FEM"

Maka dapat disimpulkan bahwa dalam penelitian ini penulis lebih memilih menggunakan pengujian dengan Random Effect Model (REM) untuk pengambilan keputusan selanjutnya.

\section{Uji F Simultan}

Berikut ini merupakan hasil output dari korelasi simultan antara variabel independen yaitu, Net profit Margin (NPM), Gross Profit Margin (GPM), Return On Investment (ROI), dan Return On Equity (ROE) dengan variabel dependen yaitu harga saham

Dimana :

$$
\begin{aligned}
& \mathrm{k}=\text { banyaknya variabel } \\
& \mathrm{n}=\text { banyaknya observasi/sampel } \\
& \text { penelitian } \\
& \mathrm{F} \text { Tabel }=\text { df } 1=\mathrm{k}-1 \\
& \text { df } 2=\mathrm{n}-\mathrm{k} \\
& \mathrm{F} \text { Tabel }=\text { df } 1=5-1 \\
& \text { df } 2=150-4
\end{aligned}
$$

Dengan dasar keputusan :

- $\quad H_{0}$ diterima jika nilai $F_{\text {hitung }} \leq F_{\text {tabel }}$

- $\quad H_{0}$ ditolak jika nilai $F_{\text {hitung }} \geq F_{\text {tabel }}$

Sehingga $F$ tabel adalah 2,37, dan nilai $F$ hitung pada model regresi random effect adalah 2,62 dengan nilai signifikan 0,03 yang berati $\mathrm{H}_{0}$ tidak dapat diterima yang berarti variabel NPM, GPM, ROI, dan ROE secara simultan berpengaruh terhdap perubahan harga saham.

\section{Uji t (t Parsial)}

Berikut ini merupakan hasil outpun uji regresi menggunakan random effect terhdapa variabel NPM, GPM, ROI, dan ROE

Dimana :

- $\quad H_{0}$ diterima jika nilai $t_{\text {hitung }} \leq t_{\text {tabel }}$

- $\quad H_{0}$ ditolak jika nilai thitung $\geq t_{\text {tabel }}$

Dimana :

$$
\begin{aligned}
\mathrm{df} & =(n-k) \\
& =(150-5) \\
& =145
\end{aligned}
$$

Maka didapatkan nilai untuk t tabel adalah 1,660 sehingga dapat disimpulkan bahwa:

1. Variabel NPM tidak berpengaruh karena nilai t hitung 1,1518 (<) kurang dari nilai $t$ tabel yaitu 1,660 dengan nilai $\rho$ 0,2513 yang berarti bahwa variabel ROI 
secara parsial tidak berpengaruh secara signifikan terhadap variabel dependen yaitu harga saham.

2. Variabel GPM tidak berpengaruh karena nilai $\mathrm{t}$ hitung $0,1189(<)$ kurang dari nilai $t$ tabel yaitu 1,660 dengan nilai $\rho 0,9055$ yang berarti bahwa variabel GPM secara parsial tidak berpengaruh secara signifikan terhadap harga saham

3. Variabel ROI berpengaruh karena nilai t hitung 3,1009 (>) lebih dari t tabel yaitu 1,660 dengan nilai $\rho$ 0,0023 yang berarti bahwa variabel ROI secara signifikan berpengaruh positif terhdap perubahan harga saham. Hal ini bertolak belakang dengan jurnal yang ditulis oleh Mochamat Feri (2014) yang menyatakan bahwa variabel ROA atau ROI tidak memiliki pengaruh terhadap perubahan harga saham. Namun hasil ini sejalan dengan Raghilia Amanah, Dwi Atmanto, dan Devi Farah Aziza (2014) yang menyatakan bahwa variabel ROI atau ROA secara signifikan berpengaruh positif terhadap perunahan harga saham.

4. Variabel ROE tidak berpengaruh karena nilai $\mathrm{t}$ hitung $0,5851 \quad(<)$ kurang dari t tabel yaitu 1,660 dengan nilai $\rho \quad 0,5594$ yang berarti variabel ROE tidak berpengaruh secara signifikan terhadap perubahan harga saham. Hasil ini bertolak belakang dengan hasil penelitian yang dilakukan oleh Mochamat Feri (2014) yang menyatakan bahwa variabel ROE berpengaruh secara signifikan terhadap perubahan harga saham. Namun hal ini sejalan dengan penelitian yang dilakukan oleh Raghilia Amanah, Dwi Atmanto, dan Devi Farah Aziza (2014) yang menyatakan bahwa variabel ROE tidak berpengaruh terhadap perunahan harga saham

Dengan persamaan regresi, yaitu : Harga Saham =

8854,183 - 164.9072 NPM - 14.79995 $\mathrm{GPM}+422,6711 \mathrm{ROI}+5.603330$ ROE

- Koefesien regresi ROI sebesar 422,6711 menyatakan bahwa setiap kenaikan Return on Invesment (ROI) sebesar $1 \%$ maka akan meningkatkan harga saham sebesar Rp. 422,6711

- Koefesien sebesar 8854,18 menunjukkan bahwa jika variabel independen $\mathrm{X} 1, \mathrm{X} 2$, dan $\mathrm{X} 3$ dianggap konstan maka rata-rata harga saham sebesar $\mathrm{Rp}$. 8845,183

\section{Koefesien Determinasi $\left(\mathbf{R}^{2}\right)$}

Berdasarkan hasil output pengujian regresi menggunakan random effects model (REM) dapat dilihat bahwa nilai adjusted $R$-Squared yaitu 0,0418, hal ini berarti 4,18\% perubahan harga saham dapat dijelaskan oleh variasi dari rasio profitabilitas (yaitu NPM, GPM, ROI dan ROE), sedangkan sisanya 95,82\% dijelaskan oleh variabel lain diluar penelitian ini, seperti faktor internal perusahaan yaitu pergantian manajerial, keputusan direksi, direksi terlibat tindak pidana, kinerja perusahaan yang terus mengalami penurunan. Kondisi eksternal perusahaan seperti, kondisi mikro dan makro ekonomi, dan efek dari psikologi perusahan yang ternyata mampu menekan kondisi teknikan jual beli saham. 


\section{E. KESIMPULAN}

Berdasarkan pembahasan yang telah dibahas melalui hasil uji Eviews 10 pada bab sebelumnya didapatkan bahwa metode Random Effects Model sebagai model persamaan regresi yang terbaik, maka dapat disimpulkan :

1. Variabel Gross Profit Margin ( GPM) secara parsial tidak signifikan berpengaruh terhadap perubahan harga saham hal ini ditunjukkandengannilait hitung 1,1518 yang kurang dari nilai $t$ tabel 1,660.

2. Variabel Net Profit Margin (NPM) secara parsial tidak signifikan berpengaruh perubahan harga saham hal ini ditunjukkandengannilait hitung 0,1189 yang kurang dari nilai $t$ tabel 1,660.

3. Variabel Returnoninvestment (ROI) secara parsial berpengaruh positif signifikan terhadap perubahan harga sahamhal ini ditunjukkan dengan nilai t hitung 3,1009 yang lebih besar dari nilai $t$ tabel 1,660.

4. Variabel Returnon Equity (ROE) secara parsial tidak signifikan berpengaruh terhadap perubahan harga sahamhal ini ditunjukkan dengan nilai t hitung 0,5851 yang kuran dari nilai t tabel 1,660 .

5. Rasio profitabilitas (NPM, GPM, $\mathrm{ROI}$, dan ROE) secara simultan berpengaruh terhadap perubahan harga saham sebesar $4,18 \%$ sedangkan sisanya 95,82 \% dipengaruhi oleh variabel lain diluar penelitian seperti kondisi makro dan mikro ekonomi, situasi dan kondisi dewan direksi, dan efek psikologis jual beli di pasar modal Indonesia.
6. Dengan persamaan regresi yaitu: Harga Saham = $8854,183-164.9072$ NPM $14.79995 \mathrm{GPM}+422,6711 \mathrm{ROI}$ $+5.603330 \mathrm{ROE}$

$>$ Koefesien regresi ROI sebesar 422,6711 menyatakan bahwa setiap kenaikan Return on Invesment (ROI) sebesar 1\% maka akan meningkatkan harga saham sebesar 422,6711 rupiah

$>$ Koefesien sebesar 8854,183 menunjukkan bahwa jika variabel independen X1, X2, X3, dan X4 dianggap konstan maka rata-rata harga saham sebesar Rp. 8845,183

Saran yang ingin penulis sampaikan pada karya ilmiah ini yaitu sebaiknya perusahaan lebih meningkatkan efektivitas perusahaan dari segi peningkatan laba bersih maupun peningkatan tingkat pengembalian dari segi investasi, hal ini dikarenakan pada hasil pengujian di karya ilmiah ini pengembalian pada segi investasi lebih di berpengaruh jika dibandingkan dengan jenis rasio profitabilitas yang lain.Pada prespektif yang lain menunjukkan bahwa rasio NPM dan ROI lebih menunjukkan pengaruh yang positif terhadap perubahan harga saham perusahaan.

\section{DAFTAR PUSTAKA}

Brigham dan Houston. 2010. Dasardasar Manajemen Keuangan Buku 1 (Edisi 11). Jakarta : Salemba Empat.

Bursa Efek Indonesia. 2018. Ringkasan Performa Perusahaan LQ45 (https://www.idx.co.id/datapasar/ringkasan-performa- 
perusahaan-lq45/

diakses

18Februari 2019)

Fahmi, Irham. 2013. Analisis Laporan Keuangan. Bandung: Alfabeta

Feri, Mochamat. 2014. Pengaruh Rasio Profitabilitas Terhadap Perubahan Harga Saham Pada Perusahaan Sektor Properti Yang Listing Di Bursa Efek Indonesia Periode 2008-2012. JurnalllmuManajemen. Vol. 2 No. 4

(http://garuda.ristekdikti.go.id/jour nal di akses 4 November 2018)

Ghozali, Imam dan Dwi Ratmono. 2017. Analisis Multivariat dan Ekonometrika (Teori, konsep, dan Aplikasi dengan Eviews 10) Edisi 2. Semarang. Badan Penerbit Universitas Diponegoro

Indrawati, Novita dan Poppy Nurmayanti M. 2010. Dasardasar Analisis Investasi dan Portofolio. Palembang:

CitrabooksIndonesia

Jogiyanto. 2008. Teori Portofolio dan Analisis Investasi Edisi Kelima. Yogyakarta. BPFE

Kasmir. 2019. Analisis Laporan Keuangan. Jakarta: Raja Grafindo Persada

Sugiyono. 2013. Metode Penelitian Pendidikan Pendekatan Kuantitatif, Kualitatif, dan $R \& D$. Bandung: Alfabeta.

Sujarweni, V. Wiratna. 2014. Metode Penelitian: Lengkap, Praktis, dan Mudah Dipahami. Yogyakarta: Pustaka Baru Press

\section{Analisis}

Laporan Keuangan. Yogyakarta: Pustaka Baru Press 